\title{
PENGARUH INFLASI INDONESIA TERHADAP PENERIMAAN PENANAMAN MODAL ASING LANGSUNG KOREA SELATAN DI INDONESIA PERIODE 2000-2014
}

\author{
Sugiartiningsih \\ Universitas Widyatama Bandung \\ Email: sugiarti.ningsih@widyatama.ac.id
}

Submitted: May 17, 2017; Reviewed: May 17, 2017; Accepted: Jun 8, 2017

\begin{abstract}
One of the keys to success in improving the economic prosperity of a country is evident from its response to bilateral or multilateral relations, particularly in the making of investments. Indonesia as a country that has started the construction of the New Order can not be separated from the role of foreign capital. In reality in the 1990s looks acceptance by the Indonesian foreign capital is relatively low compared to the developing countries in Asia. China is the largest recipient of foreign capital, followed by Singapore and Malaysia. In more remote Indonesian government continues its efforts to increase Foreign direct investment, especially from South Korea. As we all know South Korea is an important trading partner for Indonesia. Indonesia bilateral relations with South Korea have occurred since the New Order and has impacted the relatively low added value for Indonesia, especially in the 1990s. In the development of bilateral relations between the two countries increased, especially after entering the Reformation Era. This condition is supported by inflation in Indonesia is considered quite stable. This study aims to determine the effect of inflation on the acceptance Indonesia Foreign direct investment from South Korea to Indonesia during the period 2000-2014. The research methodology used is quantitative approach using simple regression model. Based on the results of the calculations, and a significant negative correlation between inflation in Indonesia and the acceptance of Direct Foreign Investment from South Korea in Indonesia. This is consistent with Fisher's theory that the decline in inflation Indonesia will be followed by a decline in interest rates Indonesia which ultimately impact the increased investment in Indonesia. Besides these reasons, the negative relationship, emphasizing that the investment climate in Indonesia has improved so trust Foreign investors, especially from South Korea in Indonesia is quite large.
\end{abstract}

Keywords: Foreign direct investment, inflation in Indonesia

\section{PENDAHULUAN}

Dalam era Globalisasi hampir dapat dipastikan setiap negara pasti berhubungan dengan negara lain baik secara bilateral maupun multilateral. Terlebih bagi negara berkembang seperti Indonesia sangat bergantung kepada perdagangan dan investasi dari luar negeri (Sabherwal et.al, 2013). Dimana untuk perdagangan luar negeri Indonesia sejak Orde Baru telah mendapatkan surplus yang besar terutama dengan negara Jepang, Amerika Serikat dan Korea Selatan sebagai mitra dagang utama Indonesia (Sugiartiningsih, 1996).

Walaupun dari sisi perdagangan telah menunjukkan keberhasilan namun dari sisi investasi ternyata belum berhasil. Sebagai realisasi dari pernyataan tersebut pada tahun 1990 an posisi Indonesia masih berada pada urutan terbawah dari sepuluh negara berkembang dalam penerimaan Penanaman Modal Asing Langsung (Faisal Basri, 1995: 222). Negara penerima Penanaman Modal Asing langsung terbesar adalah dari Cina, kemudian diikuti oleh Singapura dan Malaysia. Sedangkan Indonesia menempati peringkat terakhir dari sepuluh penerima modal asing tersebut. Hal ini menunjukkan lemahnya respon Indonesia untuk dapat membuka diri terhadap PMA langsung yang mungkin disebabkan kurang tersedianya infrastruktur dan rendahnya kebijakan yang menunjang terhadap pemasukan PMA tersebut. 
Kondisi tersebut terjadi pula pada hubungan bilateral Indonesia dengan Korea Selatan yang dinilai lebih menguntungkan bagi Korea Selatan. Sebagai realisasi dari pernyataan di atas pada semester I 1994 nilai ekspor non migas Indonesia ke Korea Selatan mengalami pertumbuhan negatif yaitu sebesar $75 \%$ sementara untuk impor Indonesia dari Korea Selatan hanya terjadi pertumbuhan sebesar 3\% (Faisal Basri,1995:228). Kegagalan Indonesia dari sisi perdagangan tersebut juga berimbas pada penurunan PMA Korea Selatan ke Indonesia dari Rp.723 milyar pada tahun 1990 menjadi Rp.661 milyar pada tahun 1993.

Penurunan nilai investasi dari PMA Korea Selatan di Indonesia tersebut merupakan cambuk bagi Indonesia untuk segera memperbaiki diri untuk dapat menjaga hubungan bilateral antara kedua negara tersebut. Menurut laporan World Development Indicators, World Bank pada tahun 2000, Indonesia berhasil mengalami surplus perdagangan barang dan jasa dengan Korea Selatan yang terlihat dari neraca berjalan sebesar USD 17,356,482,834.10 . Kondisi tersebut juga diikuti oleh realisasi investasi PMA Korea Selatan yang mencapai US\$ 690,0 juta.

Secara lebih jauh perkembangan investasi Korea Selatan di Indonesia menunjukkan adanya fluktuatif seperti terlihat pada Gambar 1 berikut:

Gambar 1. Histogram investasi dan inflasi
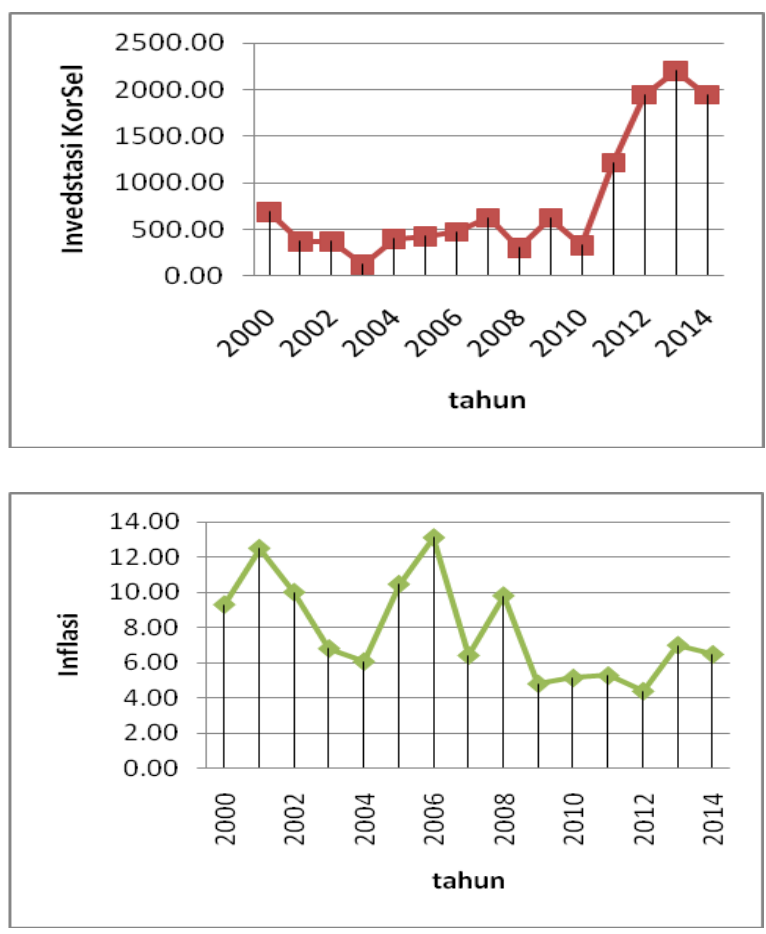

Dari Gambar 1 tersebut terlihat investasi PMA Korea Selatan mencapai nilai terendah yaitu sebesar US\$ 122,10 juta. Sedangkan dari tahun 2011 sampai dengan 2014 nilai investasi PMA Korea Selatan mampu mencapai di atas US\$ 1000 juta (Badan Pusat Statistik, berbagai tahun). Nilai investasi yang besar tersebut telah menempatkan Korea Selatan pada peringkat keempat, dimana sektor investasi terbesar pada tahun 2014 yaitu pertambangan, industri logam dasar, industri karet dan industri kulit.

Dari prestasi yang cukup besar diraih Indonesia dalam merespon PMA Korea Selatan tersebut diduga ada faktor internal yang sangat mendukung yaitu inflasi Indonesia. Seperti diketahui usaha pemerintah Indonesia dalam mengendalikan inflasi cukup keras khususnya setelah reformasi. Perkembangan inflasi di Indonesia menunjukkan kecenderungan relatif rendah sebagaimana terlihat pada Gambar 1 di atas. Sebagai contoh pada tahun 2009 inflasi Indonesia di bawah $5 \%$ yaitu $4,79 \%$ dan terus menurun hingga menjadi 4,38\% tahun 2012 . Namun pada tahun 2013 inflasi Indonesia mengalami kenaikan hingga mencapai nilai terbesar $6,98 \%$.

Dengan demikian dapat dikatakan bahwa perkembangan inflasi di Indonesia walaupun relatif stabil akan tetapi tetap terjadi fluktuatif. Kondisi tersebut diperkirakan akan mempengaruhi minat investor asing terutama dari Korea Selatan ke Indonesia. Dari fenomena tersebut maka sangatlah menarik bagi penulis untuk meneliti pengaruh inflasi Indonesia terhadap penerimaan Penanaman Modal Asing Langsung Korea Selatan di Indonesia periode 2000-2014.

\section{Perumusan Masalah}

Berdasarkan uraian dari latar belakang masalah maka rumusan masalah yang diajukan adalah sampai seberapa jauh pengaruh inflasi Indonesia terhadap penerimaan Penanaman Modal Asing Langsung Korea Selatan di Indonesia periode 2000-2014.

\section{Tujuan Penelitian}

Tujuan dari penelitian ini adalah untuk mengetahui pengaruh inflasi Indonesia terhadap penerimaan Penanaman Modal Asing Langsung Korea Selatan di Indonesia periode 2000-2014.

\section{KAJIAN TEORI}

Definisi Inflasi Dan Penanaman Modal Asing Definisi inflasi adalah kecenderungan kenaikan 
harga secara terus menerus. Jenis inflasi dapat dilihat dari faktor penyebab dan tingkatannya. Menurut Sadono Sukirno (2003) dilihat dari tingkatannya jenis inflasi dapat dibagi menjadi empat yaitu: 1) Inflasi rendah bila kurang dari 5\%; 2) Inflasi sedang bila berkisar dari 5 hingga kurang dari 10\%; 3) Inflasi tinggi bila terjadi mulai $10 \%$ ke atas; 4) Inflasi hiper bila inflasi mencapai ratusan hingga milyaran persen.

Sedangkan dilihat dari faktor penyebabnya inflasi dapat disebabkan oleh permintaan dan penawaran. Dimana untuk sisi permintaan yang dikenal dengan istilah demand full inflation secara umum terjadi bila masyarakat suatu negara sedang mengalami kesejahteraan tinggi atau mengalami boom ekonomi. Sebaliknya inflasi sisi penawaran yang dikenal dengan istilah cost push inflation disebabkan oleh tingginya biaya ekonomi yang dialami oleh perusahaan akibat tuntutan kenaikan upah buruh, harga bahan baku dan pencabutan subsidi BBM.

Selain pemilahan seperti di atas inflasi juga dapat dibedakan dari asal negara yaitu inflasi domestik dan inflasi luar negeri atau import inflation. Inflasi dari dalam negeri bila terjadi kenaikan akan berdampak naiknya harga komoditi dalam negeri dan akan mendorong suatu negara untuk cenderung mengimpor. Sebaliknya inflasi luar negeri disebabkan kondisi negara lain yang mungkin terjadi adanya suatu krisis (Tambunan, 2014).

Investasi atau penanaman modal adalah kegiatan untuk menambah barang-barang dan jasa-jasa yang tersedia dalam perekonomian yang bertujuan untuk memperoleh keuntungan. Investasi dilihat dari jenisnya dapat dibagi menjadi empat pasang yaitu: 1) Autonomous investment dan induced investment; 2) Public investment dan privat investment; 3) Domestic investment dan foreign investment serta; 4) Gross investment dan net investment(Samuelson,2005).

Dari keempat jenis investasi tersebut maka foreign investment adalah kegiatan penanaman modal ke negara lain. Dilihat dari tujuannya foreign investment atau penanaman modal asing dapat dikelompokkan menjadi dua yaitu investasi langsung dan investasi portfolio (Sabherwal et.al, 2013). Investasi Asing Langsung yang diistilahkan Foreign Direct Investment (FDI) adalah penanaman modal asing yang lebih terfokus pada suatu proyek. Berarti lebih mengacu pada arus masuk bersih dari investasi untuk memperoleh suatu kepentingan manajemen abadi (10 persen atau lebih dari saham voting) dalam suatu operasi perusahaan dalam suatu perekonomian selain dari investor. Hal ini meliputi jumlah modal, reinvestasi pendapatan, modal jangka panjang lainnya dan modal jangka pendek seperti yang disajikan dalam neraca pembayaran. Jenis FDI terbagi dua yaitu investasi langsung ke dalam negeri dan investasi asing ke luar negeri sehingga diperoleh FDI bersih baik positif maupun negatif serta saham investasi langsung dalam periode tertentu. Sedangkan investasi portfolio internasional hanyalah dilakukan dalam pembelian saham, obligasi dan sekuritas keuangan internasional lainnya di pasar modal negara lain.

Investor yang berperan dalam Investasi Asing Langsung dapat diklasifikasikan dalam sektor ekonomi seperti individu, sekelompok individu terkait, badan yang didirikan atau unincorporated, sebuah perusahaan publik atau perusahaan swasta, kelompok perusahaan terkait, badan pemerintah, lembaga sosial lainnya atau kombinasi seluruh sektor ekonomi. Kemudian untuk dapat memperoleh hak suara dari perusahaan dalam suatu perekonomian maka metode yang harus diikuti oleh investor langsung asing adalah dengan memasukkan anak perusahaan yang sepenuhnya dimiliki, mengakuisisi saham di perusahaan asosiasi, melalui merger suatu perusahaan yang tidak terkait dan berpartisipasi dalam ekuitas usaha patungan dengan investor lain atau perusahaan.

Penanaman investasi langsung asing dapat mengambil keuntungan dari sisi ekonomi. Bentuk-bentuk keuntungan ekonomi yang dapat diperoleh dalam penanaman investasi langsung asing yaitu pajak korporasi yang rendah, pajak liburan, lain jenis konsesi pajak, preferensial tarif, ekonomi zona khusus, EPZ - Zona Pemrosesan Ekspor, gudang berikat, maquiladora, investasi subsidi keuangan, pinjaman lunak atau jaminan pinjaman, tanah bebas atau tanah subsidi, relokasi \& subsidi kerja, infrastruktur subsidi, R \& D support dan pengurangan dari peraturan khususnya untuk proyek yang sangat besar.

Sanksi dalam penanaman investasi langsung asing telah diatur menurut ketentuan UU No. 25 Tahun 2007 pasal 33 dan 34. Dimana sanksi dalam penyelenggaraan modal meliputi : 1) Sanksi batal demi hukum; 2) Sanksi pembatalan kontrak kerja sama; 3) Sanksi administrasi dan 4) Sanksi pidana. 


\section{Pengaruh Inflasi Dalam Negeri Terhadap Penanaman Modal Asing}

Kondisi inflasi dalam negeri suatu negara sangat berpengaruh terhadap respon investor asing langsung dalam menanamkan modalnya. Apabila inflasi suatu negara sangat tinggi maka akan diikuti oleh kondisi kenaikan harga-harga yang dapat mengurangi minat investor asing untuk menanamkan modal ke negara tersebut. Sebaliknya apabila inflasi suatu negara terlihat lebih stabil pada tingkatan yang rendah maka akan mendorong respon investor asing untuk menanamkan modal pada suatu negara. Dengan demikian penerimaan penanaman modal asing langsung juga akan terus meningkat sebagai akibat dari turunnya inflasi dalam negeri suatu negara (Sadono Sukirno, 2003).

Pengaruh inflasi dalam negeri terhadap penerimaan Modal Asing Langsung oleh suatu negara dapat pula dijelaskan melalui Fisher Effect (Mahyus Ekananda, 2015). Dalam teori tersebut para ekonom membedakan antara suku bunga nominal dan suku bunga riil. Suku bunga nominal adalah rate yang dapat diamati di pasar, sedangkan suku bunga riil adalah konsep yang mengukur tingkat kembalian setelah dikurangi dengan inflasi (Melvin, 1985). Efek ekspektasi inflasi terhadap suku bunga nominal sering disebut efek Fisher (Fisher effect) dan hubungan antara inflasi dan suku bunga ditunjukkan dengan persamaan Fisher. Rumusan ini berasal dari penurunan rumus:

$$
i=\left[\left(1+i_{r}\right)\left(1+\pi_{e}\right)\right]-1, \text { dengan operasi }
$$

distributive diperoleh

$$
i=i_{r}+\pi_{e}+i_{r} \pi_{e}
$$

perkalian $i_{r} \pi_{e}$ terlalu kecil, sehingga : $i=i_{r}+\pi_{e}$

Dari persamaan di atas menunjukkan bahwa tingkat suku bunga nominal (i) sama dengan tingkat suku bunga riil $\left(i_{r}\right)$ ditambah oleh ekspektasi inflasi $\left(\pi_{e}\right)$. Disamping itu persamaan tersebut juga mengindikasikan bahwa tingkat suku bunga dapat berubah oleh dua hal, pertama oleh perubahan tingkat suku bunga riil $\left(i_{r}\right)$ dan kedua, oleh perubahan ekspektasi inflasi $\left(\pi_{e}\right)$. Hal tersebut dapat diartikan, peningkatan ekspektasi inflasi akan cenderung meningkatkan suku bunga nominal. Oleh karenanya pada suku bunga nominal akan cenderung terkandung ekspektasi inflasi untuk memberikan tingkat kembalian riil atas penggunaan uang.

Sesuai teori Fisher bila inflasi suatu negara meningkat maka akan diikuti oleh kenaikan suku bunga dalam negeri. Dilain pihak kondisi suku bunga suatu negara sangat berpengaruh terhadap keputusan investor asing untuk menanamkan modalnya. Berarti pengaruh inflasi terhadap Penanaman Modal Asing Langsung di suatu negara terjadi secara tidak langsung melalui pengaruhnya pada bunga domestik.

Berdasarkan pernyataan tersebut bila inflasi suatu negara tinggi maka akan diikuti oleh kenaikan suku bunga dalam negerinya. Kondisi ini akan mendorong turunnya penerimaan investasi suatu negara. Hal ini sebagaimana dikemukakan dalam teori Klasik bahwa ada hubungan terbalik antara suku bunga dalam negeri dan besarnya penerimaan investasi oleh suatu negara (Sadono Sukirno, 2003). Dengan demikian bila inflasi suatu negara meningkat maka akan diikuti oleh kenaikan suku bunganya yang selanjutnya akan mendorong turunnya jumlah investasi yang diterima oleh negara tersebut.

\section{Kerangka Pemikiran}

Penanaman Modal Asing ke Indonesia yang bertujuan untuk meningkatkan kesejahteraan ekonomi sangat dipengaruhi oleh stabilitas ekonomi dalam negeri. Pengukuran stabilitas ekonomi antara lain dapat dilihat dari variabel inflasi. Bila inflasi dalam negeri relatif tinggi maka akan mendorong naiknya suku bunga dalam negeri sehingga akan menurunkan minat investor asing untuk menanamkan modalnya ke Indonesia.

Dengan demikian kestabilan nilai inflasi di Indonesia dalam perekonomian dunia sangat diperlukan supaya penerimaan modal asing seperti PMA Langsung Korea Selatan dapat meningkat. Disamping itu stabilitas inflasi tersebut juga penting bagi kedua negara karena turunya harga-harga di Indonesia akan mendorong daya beli masyarakat akan naik dan kondisi ini akan diikuti oleh minat investor asing Korea Selatan untuk menanamkan modalnya di Indonesia.

Pengaruh Inflasi Indonesia Terhadap Penerimaan Penanaman Modal Asing Langsung Korea Selatan Di Indonesia.

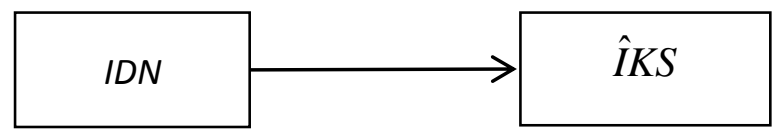

\section{Hipotesis Penelitian}

Pengaruh inflasi Indonesia terhadap penerimaan Penanaman Modal Asing langsung Korea Selatan di Indonesia. 
Penurunan inflasi di Indonesia akan mendorong turunnya suku bunga dalam negeri. Hal ini sesuai dengan Teori Fisher bahwa ada hubungan positif antara kedua variabel tersebut. Selanjutnya turunnya suku bunga akan diikuti kenaikan penanaman modal asing langsung dari negara lain yaitu Korea Selatan.

Penelitian yang membahas faktor-faktor yang berpengaruh terhadap investasi telah dilakukan penulis sebelumnya (2015) yang bertujuan melihat pengaruh suku bunga dalam negeri terhadap total investasi Indonesia selama periode 1994 - 2014. Ternyata dari hasil pengolahan data terlihat adanya pengaruh negatif dan signifikan.

Penelitian yang lebih terfokus pada investasi portofolio juga telah dilakukan Acep Edison, Sugiartiningsih, Tria Apriliana (2016) yang bertujuan mengetahui apakah ada pengaruh variabel ekonomi antara lain inflasi, suku bunga Bank Indonesia dan nilai tukar rupiah terhadap return saham di sektor manufaktur di Indonesia Stock Exchange periode 2010 - 2014. Analisis data dilakukan dengan menggunakan persamaan Structural Modeling (SEM), diperoleh hasil bahwa inflasi dan nilai tukar secara parsial mempengaruhi return saham, sedangkan suku bunga tidak berpengaruh terhadap return saham. Namun secara simultan ketiga variabel tersebut mempengaruhi return saham.

Dari hasil penelitian total investasi terdapat kelemahan yaitu hanya menekankan pengaruh langsung suku bunga terhadap investasi. Dari hasil pengolahan data walaupun signifikan akan tetapi kontribusi kuarang dari $50 \%$. Sedangkan menurut dasar berpikir teoritis variabel utama yang memperkuat suku bunga adalah inflasi dalam negeri. Dengan mengingat kurangnya respon penelitian terhadap pengaruh inflasi terhadap investasi, sehingga dimasukkan variabel inflasi dalam negeri sebagai faktor yang diduga berpengaruh terhadap pnerimaan Penanaman Modal Asing Langsung Indonesia dari Korea Selatan.

$\mathrm{Ha}$ : Inflasi Indonesia akan berpengaruh negatif terhadap penerimaan Penanaman Modal Asing Langsung Korea Selatan di Indonesia.

\section{METODE PENELITIAN}

Metode penelitian yang digunakan adalah pendekatan diskriptif analisis yang bertujuan memberikan gambaran hubungan kausal antara suku bunga dalam negeri dengan penerimaan Penanaman Modal Asing Langsung Korea Selatan di Indonesia. Tehnik pengumpulan data dengan menggunakan data sekunder yang bersumber dari Badan Pusat Statistik dan Asian Development Bank. Periode data penelitian dari tahun 2000 sampai dengan 2014 karena tahun 2000 merupakan kebangkitan perekonomian Indonesia setelah terjadi krisis nilai tukar di Indonesia, dan tahun 2014 merupakan puncak prestasi perekonomian Indonesia dalam merespon penerimaan Penanaman Modal Asing di Indonesia di masa pemerintahan SBY II.

Pemodelan hubungan inflasi Indonesia dengan penerimaan Penanaman Modal Asing Langsung Korea Selatan di Indonesia selama periode 2000 - 2014 dengan menggunakan persamaan regresi sebagai berikut:

dimana:

$$
I K S=a+b I D N
$$

$I K S$ = nilai Penanaman Modal Asing Korea Selatan Langsung di Indonesia yang diregres terhadap suku bunga dalam negeri (satuan mata uang)

$I D N=$ inflasi Indonesia dengan menggunakan data Consumtion Price Index (\%)

\section{Rancangan Uji Hipotesis}

Uji Parsial Persamaan Regresi

Persamaan Pengaruh Inflasi Indonesia Terhadap penerimaan penanaman Modal Asing Langsung Korea Selatan Di Indonesia Periode 2000-2014. Inflasi Indonesia berpengaruh terhadap penerimaan Penanaman Modal Asing Langsung Korea Selatan di Indonesia.

$\mathrm{H}_{0}: \rho>0$ Inflasi Indonesia berpengaruh positif terhadap penerimaan Penanaman Modal Asing Langsung Korea Selatan di Indonesia.

Ha: $\rho<0$ Inflasi Indonesia berpengaruh negatif terhadap penerimaan Penanaman Modal Asing Langsung Korea Selatan di Indonesia.

\section{HASIL DAN PEMBAHASAN \\ Hasil}

Perhitungan koefisien untuk persamaan regresi dari data-data tahun 2000-2014 diperoleh hasil: $I K S=1638,980318-106,6081568 I D N$ Pada persamaan di atas IKS adalah variabel penerimaan Penanaman Modal Asing Langsung Korea Selatan di Indonesa, sedangkan IDN adalah variabel inflasi Indonesia. Bila IDN belum ada maka nilai penerimaan Penanaman Modal Asing Langsung Korea Selatan di Indonesia adalah sebesar US\$1638,980318 juta. Inflasi Indonesia memiliki hungan negatif 
terhadap nilai penerimaan Penanaman Modal Asing Langsung korea Selatan di Indonesia. Jika inflasi Indonesia terjadi kenaikan sebesar $1 \%$ maka nilai penerimaan Modal Asing Langsung Korea Selatan di Indonesia akan turun sebesar US\$ 1638,980318 juta.

\section{Pengujian Statistik}

Analisis signifikansi dari nilai koefisien persamaan dari model regresi sederhana dilakukan dengan pengujian statistik yaitu uji tstatistik.

\section{Uji Parsial Persamaan Regresi}

Ha : Inflasi Indonesia akan berpengaruh negatif terhadap penerimaan Penanaman Modal Asing Langsung Korea Selatan di Indonesia.

Dari hasil pengujian t-statistik didapat variabel inflasi Indonesia memiliki koefisien 4,87046. Nilai t-hitung tersebut terbukti lebih besar dari t-tabel pada taraf signifikansi $1 \%$ (ttabel $=-3,012$ ).

\section{Pembahasan}

Persamaan Pengaruh Inflasi Indonesia Terhadap Penerimaan Penenaman Modal Asing Langsung Korea Selatan Di Indonesia Periode 2000 - 2014

$\mathrm{Ha}$ : Inflasi Indonesia berpengaruh negatif terhadap penerimaan Penanaman Modal asing Langsung Korea Selatan Di indonesia

Variabel inflasi Indonesia berhubungan negartif terhadap penerimaan Penanaman Modal Asing Langsung Korea Selatan di Indonesia. Hal ini sudah sesuai dengan teori Efek Fisher yang menekankan adanya hubungan searah antara inflasi dan suku bunga dalam negeri suatu negara. Apabila inflasi Indonesia terjadi penurunan maka akan diikuti oleh penurunan suku bunga di Indonesia. Menurut kaidah ekonomi makro turunnya suku bunga Indonesia akan mendorong produktivitas suatu negara dengan naiknya penanaman modal (Samuelson, 2005). Dengan demikian akan berpeluang bagi Indonesia untuk dapat meningkatkan penerimaan modal asing khususnya Penanaman Modal Asing Langsung Korea Selatan di Indonesia.

Sebagai realisasi dari pernyataan tersebut penanaman modal di Indonesia masih dikuasai investor asing yaitu sebesar 60\% (Megasari Jauhari Putri, 2017). Korea Selatan merupakan salah satu negara asing yang berminat untuk menanamkan modalnya di Indonesia. Kondisi tersebut terlihat dari sikap Indonesia yang terus memperkuat kerjasama penanaman modal 38 dengan Korea Selatan. Adapun cara yang ditempuh adalah melalui negosiasi IK-CEPA (Indonesia Korea-Comprehensive Economic Partnership Agreemant) pada tanggal 29-30 September 2014. Hasil dari pertemuan tersebut kedua pihak sepakat untuk mengakselerasi kerjasama bilateral dengan memprioritaskan 10 proyek utama yaitu Kerjasama Kawasan Ekonomi Khusus, Kerjasama Industri Perkapalan, Agro-based Multi-Industry Cluster (MIC), kerjasama mesin-mesin pertanian, Jakarta Giant Sea Wall, Pekanbaru City Water Suppy, Restorasi Kali Ciliwung di Jakarta, Restorasi Sungai Citarum, Karian Water Conveyance dan Coal-fired Steam power Plant. Investasi Korea Selatan di Indonesia terutama pada sektor industri elektronik, telekomunikasi, konstruksi, otomotif, pertambanagn, migas, air bersih, perbankan dan perhotelan.

Kepercayaan FDI Korea Selatan di Indonesia tersebut tentu didukung faktor internal yang sangat penting yaitu inflasi Indonesia. Selama periode yang diteliti inflasi Indonesia menunjukkan kecenderungan menurun sehingga akan berdampak pula terhadap penurunan suku bunga di Indonesia. Dengan mengingat inflasi merupakan faktor utama yang memperkuat penanaman modal di Indonesia sehingga penurunan suku bunga tersebut akan berdampak pada peningkatan penerimaan FDI Korea Selatan di Indonesia. Sebagai bukti hingga tahun 2014 Investasi Korea Selatan di Indonesia mencapai pertumbuhan $7,6 \%$ dan berada di peringkat lima teratas sehingga menjadikan Korea selatan sebagai salah satu sumber utama investasi di Indonesia

(https://www.suara.com/bisnis/2016/03/12/19510 0/bkpm-korea-salah-satu-sumber-utamainvestasi-di-indonesia)

Disamping alasan tersebut rendahnya inflasi Indonesia juga berdampak terhadap pasar barang dan jasa yaitu dapat menigkatkan daya beli masyarakat dan produktivitas investor. Jika inflasi Indonesia turun maka suku bunga pinjaman juga turun sehingga memberikan risiko yang rendah bagi investor dalam pengembalian pinjaman yang pada taraf berikutnya akan menaikkan produktivitas investor Korea Selatan untuk penanaman modal langsung di Indonesia. Penekanan inflasi tersebut sekaligus menggambarkan stabilitas ekonomi yang mendorong iklim investasi di Indonesia sehingga akan berdampak terhadap kenaikan penerimaan FDI Korea Selatan di Indonesia. 
Demikian pula dilihat dari persepsi masyarakat Indonesia kemampuan pemerintah menekan inflasi sedikit banyak berpengaruh terhadap naiknya daya beli masyarakat baik terhadap barang domestik maupun impor. Terlebih jika mengingat masyarakat Indonesia tergolong sangat konsumtif terutama terhadap barang dan jasa dari Korea Selatan maka kondisi inflasi tersebut akan menguntungkan investor Korea Selatan untuk menanamkan modalnya di Indonesia. Seperti diketahui hampir sebagian besar alat pemuas kebutuhan masyarakat dipenuhi dari impor mulai kebutuhan primer, sekunder dan tersier. Bahkan ketimpangan distribusi pendapatan di Indonesia turut menciptakan pola konsumsi tinggi karena rasa gengsi atau gaya hidup wah yang terjadi pada kelompok masyarakat atas(Tempo,2017). Dampaknya daya beli masyarakat akan naik terhadap barang-barang mewah yang harus dimpor dari Korea Selatan. Dengan demikian rendahnya inflasi Indonesia akan memperkuat iklim investasi di Indonesia.

\section{KESIMPULAN DAN SARAN Kesimpulan}

Pada persamaan pengaruh inflasi Indonesia terhadap penerimaan Penanaman Modal Asing Langsung Korea Selatan di Indonesia, arah koefisien inflasi Indonesia sudah sesuai teori ekonomi yaitu berpengaruh negatif terhadap penerimaan Penanaman Modal asing Langsung Korea Selatan di Indonesia.

\section{Saran}

Untuk dapat mengetahui secara optimal penerimaan Penanaman Modal Asing Langsung Korea Selatan di Indonesia pada masa mendatang perlu diperluas faktor-faktor makro yang lainnya seperti nilai tukar, pertumbuhan ekonomi dan sebagainya.

\section{DAFTAR PUSTAKA}

Acep E., Sugiartiningsih \& Tria A. (2016). The Effect of Inflation, BI Rate, and Rupiah Exchange Rate on Stock Returns and Its Effect on Return on Investment (Study on Manufacturing Sector of Industry listed in Jakarta-Indonesia Stock Exchange period 2010-2014), WISS, Bandung: 6-9 Sept. 2016.

\footnotetext{
Asian Development Bank, CPI, http://www.adb.org/publications/keyindicators-asia-and-pacific-2016
}

Badan Koordinasi Penanaman Modal, Berbagai Tahun.

Badan Pusat Statistik, Penanaman Modal Asing, BPS, Jakarta: 2016.

Faisal B. (1995). Perekonomian Indonesia Menjelang Abad XXI: Distorsi, Peluang dan Kendala, Penerbit Erlangga: Jakarta

Gujarati. (2003). Basic Econometrics Fourth Edition, Damodar N. Gujarati, McGraw Hill Book

https://www.suara.com/bisnis/2016/03/12/19510 0/bkpm-korea-salah-satu-sumber-utamainvestasi-di-indonesia

Mahyus E. (2015). Ekonomi Internasional, Penerbit Erlangga:Jakarta

Megasri J.P. (2017). Struktur Pasar modal Indonesia, Kuliah Umum Seminar Pasar Modal, Fakultas Ekonomi Universitas Widyatama, Bandung: 14 Maret 2017

Sabherwal, E. (2013). Keuangan Internasional Edisi Keenam Buku 1, Salemba Empat, Jakarta

Sadono S. (2003). Makroekonomi Teori Pengantar Edisi Kedua, PT Raja Grafindo Persada, Jakarta

Samuelson, P.A \& Wiliam D. N. (2005) Economics, $18^{\text {th }}$ ed. Mc-Graw-Hill

Sugiartiningsih. (1996). Analisis Fluktuasi Kurs Dollar Amerika dan Pengaruhnya terhadap Neraca Perdagangan Indonesia Amerika. Tesis, Program Pasca Sarjana Universitas Padjadjaran, Bandung

Sugiartiningsih. (2015). Pengaruh Suku bunga Dalam Negeri Terhadap Total Investasi Indonesia Sebagai Upaya Merespon Pasar Persaingan Indonesia dalam Era Globalisasi. MEBC: Peluang Indonesia dalam Persaingan Ekonomi Kreatif Global, Universitas Kristen Maranatha, Bandung

Tempo. (2017). Laporan Khusus Ketimpangan Ekonomi, Jakarta: 20-26 Maret 2017.

Tambunan, T.H.T. (2014). Perekonomian Indonesia, Kajian Teoritis dan Analisis Empiris, Ghalia Indonesia 
Jurnal Manajemen Maranatha — Vol. 17 Nomor 1, November (2017) 